\title{
Hydraulic binder obtained from recycled cement and sand powder
}

\section{Aglomerante hidráulico obtido de cimento reciclado e pó de areia}

R. M. R. O. MENEZES raquelmrom@ufmg.br

R. M. DA SILVA a roberto@dees.ufmg.br

E. P. FIGUEIREDO epazini@terra.com.br

A. C. DA SILVA BEZERRA c augustobezerra@des.cefetmg.br

M. T. P. AGUILAR d teresa@ufmg.br

P. R. CETLIN pcetlin@demec.ufmg.br

\begin{abstract}
Environmentally eco-efficient concrete is currently a popular choice of construction material. Reviewing relevant literature indicates that heating of cement paste can remove hydrating water, and that quartz sand of appropriate granulometry can act as a supplementary cementitious material; however, there have been virtually no reports on the reuse of these materials as alternative binders. This work evaluates the phases present in cementitious compounds produced with binders obtained by thermomechanically treating cement pastes with and without a $15 \%$ substitution of quartz sand powder (specific surface area $37.4 \mathrm{~m}^{2} / \mathrm{g}$ ), referred to as RCQ and recycled cement RC, respectively. Testing included thermogravimetric analysis (performed with stripped gases), X-ray diffraction, and scanning electron microscopy with phase identification. The obtained data indicated RC cement paste possesses a predominantly ettringite microstructure, whereas the presence of calcium hydroxide and hydrated calcium silicate predominates in RCQ paste.
\end{abstract}

Keywords: construction residues, sand functionalization, cement microstructure, thermal analysis, X-ray diffraction.

\section{Resumo}

Atualmente tem-se buscado a obtenção de concretos ecoeficientes por meio da reciclagem dos resíduos de concreto. Estudos da literatura mostram que o aquecimento da pasta pode remover a água de hidratação e que areia quartzosa pode atuar como material cimentício suplementar quando na granulometria adequada. Entretanto, praticamente inexistem relatos sobre reuso desses materiais como aglomerantes alternativos. Este trabalho avalia as fases presentes em compostos cimentícios confeccionados com aglomerante obtido do tratamento termomecânico de pastas com $15 \%$ de pó de areia quartzosa (RCQ) e sem substituição (RC) com superfície específica de 37.4 m²/g. Foram realizadas termogravimetrias com análise de gases desprendidos, difração de raios X e microscopia eletrônica de varredura com identificação de fases. Os dados obtidos mostram que a pasta RC possui microestrutura predominante de etringita enquanto na pasta RCQ predomina a presença de hidróxido de cálcio e silicato de cálcio hidratado.

Palavras-chave: análise térmica, difração de raios-x, funcionalização de areia, microestrutura, resíduos de construção. 


\section{Introduction}

Hardened Portland cement paste is composed primarily of hydrated calcium silicate, calcium hydroxide, calcium sulfoaluminates, non-hydrated cement particles, and water (Taylor et al. [1]). According to Mehta and Monteiro [2], cement paste contains chemically combined, capillary, adsorbed, and interlamellar water, the latter three types which can be lost by drying and may cause material shrinkage. Chemically combined water, however, is only released when hydrated products decompose because of heating.

Taylor et al. [1] analyzed the hydration of Portland cement using X-ray diffraction, thermal analysis, and infrared spectroscopy methods, which are considered satisfactory for describing this phenomenon. Other studies on Portland cement compound hydration levels have been based only on thermal analyses of hydrated-phase decomposition products (Taylor et al. [1]; Shui et al. [3]; Lemonis et al. [4]). Various studies have identified the existence of seven different reactions involved in the decomposition of the cementitious paste: five dehydration reactions, one dehydroxylation reaction, and one decarbonation reaction (Fordham and Smalley [5]). The five dehydration reactions are related to chemically combined, interlamellar, capillary, and adsorbed water losses. Kovler and Roussel [6] and Schöler et al. [7] conducted studies on the hydration and dehydration kinetics of Portland cement through different curing processes and additions. The influence of superplasticizers on the hydration process has also been investigated using atomic modeling techniques (Karen et al. [8]).

Various studies have addressed the rehydration of cement after high temperature exposures. Farage et al. [9] analyzed the behavior of cement pastes with a 0.5 water-cement ratio $(\mathrm{w} / \mathrm{c})$ subjected to temperatures of up to $300{ }^{\circ} \mathrm{C}$ and found it was possible to rehydrate both calcium silicates and non-hydrated grains. Other studies have confirmed the recovery of cement phases subjected to temperatures up to 1,400 ${ }^{\circ} \mathrm{C}$ and verified phases are recoverable when subjected to temperatures similar to those used in the clinker process, although their reuse is restricted to mortar applications (Splittgerber and Mueller [10]). Various researchers have evaluated the microstructure of cement pastes after heat exposure (Burgh and Foster [11]), slow heating, and cooling cycles. They cement pastes with $0.4 \mathrm{w} / \mathrm{c}$ have been found to lose waterrelated hydration mass at $750{ }^{\circ} \mathrm{C}$ (Alonso and Fernandez [12]). According to Wang et al. [13], cured cement pastes exposed to temperatures of $400{ }^{\circ} \mathrm{C}$ maintain a constant pore structure and phase composition, whereas the same cement pastes subjected to $800{ }^{\circ} \mathrm{C}$ temperatures may exhibit new hydration products and refined pore structures.

Zanni et al. [14] investigated the behavior of crushed quartz in reactive powder concrete, verifying its low reactivity at approximately ambient temperatures. Klimesch and Ray [15] evaluated the ef- fects of ground quartz surface area on the chemical and physical properties of autoclaved cement pastes using larger particles (0.68 $\mathrm{m}^{2} / \mathrm{g}$ ), and verified these particles acted as nucleating agents, accelerating the formation of calcium silicates and calcium hydroxide. Benezet and Benhassaine [16] confirmed samples of quartz powders may exhibit reactivity with calcium hydroxide, provided they have an average size $\leq 5 \mu \mathrm{m}$. Deschner et al. [17] investigated the hydration of Portland cement using quartz powder and siliceous fly ash with similar granulometries. Under these conditions, they verified that quartz did not exhibit pozzolanic behavior when exposed to ambient temperature $\left(23^{\circ} \mathrm{C}\right)$.

Even when considering the reactivity of sand and possibility of cement rehydration, the reuse of cement and quartz sand as alternative binders has not been reported in literature. This study compared the phases present in cement pastes produced from anhydrous Portland cement and binders, obtained from the thermomechanical treatment of Portland cement pastes with and without the presence of ground quartz sand (sand powder). The objective was to analyze the technical viability of reusing the sand and cement present in mortar residues utilizing thermomechanical treatment.

\subsection{Rationale}

The overall consumption of Portland cement has increased over the past three decades, a phenomenon primarily attributed to increasing urbanization and industrialization in countries with emerging economies, as well as the versatility and relatively low cost of the binding materials (SNIC - Sindicato Nacional da indústria do cimento [18]).

The production of Portland cement, however, negatively impacts environmental concerns such as natural resources and the climate, and contributes substantially to $\mathrm{CO}_{2}$ emissions as these are an intrinsic part of its production process. Partial clinker/cement substitutions, particularly those utilizing construction, industrial, and agricultural residues, could thus function as an environmentally efficient concrete alternative.

This study investigated the possibility of reusing dehydrated cement paste and quartzous fine aggregate products, both of which are present in concrete residues, to obtain cementitious and supplementary cementitious materials. Such an approach may contribute to the environmentally friendly disposal of these residues, and could also reduce the environmental impact and carbon dioxide emissions of cement production.

\section{Materials and methods}

This analysis utilized Portland cement, with a high initial strength

\section{Table 1}

Physical characterization of high initial strength Portland cement

\begin{tabular}{|c|c|c|c|c|c|c|c|c|c|}
\hline \multirow{2}{*}{$\begin{array}{l}\text { Initial } \\
\text { setting } \\
\text { times } \\
(\min )\end{array}$} & \multirow{2}{*}{$\begin{array}{l}\text { Final } \\
\text { setting } \\
\text { times } \\
\text { (min) }\end{array}$} & \multirow{2}{*}{$\begin{array}{c}\text { Loss on } \\
\text { ignition } \\
1,000^{\circ} \mathrm{C} \\
(\%)\end{array}$} & \multirow{2}{*}{$\begin{array}{c}\text { Loss on } \\
\text { ignition } \\
500^{\circ} \mathrm{C} \\
(\%)\end{array}$} & \multirow[b]{2}{*}{$\begin{array}{l}\text { Insoluble } \\
\text { residue (\%) }\end{array}$} & \multirow{2}{*}{$\begin{array}{c}\text { Specific } \\
\text { surface } \\
\text { area } \\
\text { (Blaine) } \\
\left(\mathrm{m}^{2} / \mathrm{kg}\right)\end{array}$} & \multirow{2}{*}{$\begin{array}{c}\text { Specific } \\
\text { mass } \\
\left(\mathrm{g} / \mathrm{cm}^{3}\right)\end{array}$} & \multicolumn{3}{|c|}{ Compressive strength (MPa) } \\
\hline & & & & & & & 3 days & 7 days & 28 days \\
\hline 131 & 185 & 3.5 & 0.7 & 0.8 & 470.8 & 3.11 & 30 & 46 & 55 \\
\hline
\end{tabular}


Table 2

Chemical characterization of Portland cement

\begin{tabular}{cccccc}
\hline $\begin{array}{c}\mathrm{SiO}_{2} \\
(\%)\end{array}$ & $\begin{array}{c}\mathrm{Al}_{2} \mathrm{O}_{3} \\
(\%)\end{array}$ & $\begin{array}{c}\mathrm{CaO} \\
(\%)\end{array}$ & $\begin{array}{c}\mathrm{SO}_{3} \\
(\%)\end{array}$ & $\begin{array}{c}\mathrm{CO}_{2} \\
(\%)\end{array}$ & $\begin{array}{l}\mathrm{C}_{3} \mathrm{~A} \\
(\%)\end{array}$ \\
\hline $\mathrm{C} 20$ & $\mathrm{C} 20$ & $\mathrm{C} 20$ & $\mathrm{C} 20$ & $\mathrm{C} 20$ & $\mathrm{C} 20$ \\
\hline
\end{tabular}

\section{Table 3}

\section{Chemical characterization of Portland cement}

\begin{tabular}{ccc}
\hline $\begin{array}{c}\text { Specific surface } \\
\text { area }(\mathrm{BET})\left(\mathrm{m}^{2} / \mathrm{kg}\right)\end{array}$ & $\begin{array}{c}\text { Mean diameter } \\
(\mu \mathrm{m})\end{array}$ & $\begin{array}{c}\text { Pozzolanicity - } \\
\text { Chapelle modified } \\
(\mathrm{mg} / \mathrm{g} \mathrm{CaO})\end{array}$ \\
\hline 37,400 & 3.6 & 958.2 \\
\hline
\end{tabular}

and low additive content; anhydrous cement (R), shown in Tables 1 and 2; potable water; and quartz sand powder, produced by grinding to achieve an average particle size of $3.6 \mu \mathrm{m}$ (Table 3). Grinding was performed in a high energy planetary mill (Planetary Mill Pulverisette 5) at $300 \mathrm{rpm}$ using grinding vessels and zirconium oxide balls. Cement fineness was evaluated by measuring the specific surface area using a Blaine permeability apparatus. The specific surface areas of sand samples were determined using the linearized Brunauer, Emmett and Taller (BET) method in the relative pressure range of $0.05-0.30$, achieved with branded equipment from Quantachrome Instruments (Nova Station A-1200e Surface Area and Pore Size Analyzer). Nitrogen gas was used as an adsorbate during testing. Samples were treated at $200{ }^{\circ} \mathrm{C}$ for $5 \mathrm{~h}$ prior to contact with the gas.

Experiments were conducted in two stages. In the first one, temperatures most suitable for recovering the anhydrous phases of cements were determined by means of thermal analysis in the DTG$60 \mathrm{H}$ Shimadzu apparatus (atmospheric air and heating rate of 10 ${ }^{\circ} \mathrm{C} / \mathrm{min}$ ). Portland cement paste of $0.5 \mathrm{w} / \mathrm{c}$, comminuted after a 28 day water immersion curing, was used for this purpose. Considering the obtained results, cement paste samples were subjected to temperatures of $200,500,550$, and $700{ }^{\circ} \mathrm{C}$ in the same equipment used for thermogravimetric analysis (TGA). These samples were analyzed by X-ray diffraction (XRD) with the Philips-PANalytical PW 1710 equipment, using CuKa radiation, $40 \mathrm{kV}$ power, and an electric current of $30 \mathrm{~mA}$.

In the second experimental stage, Portland cement pastes (AC pastes) were produced with the same parameters as those in step 1. Some samples were ground to achieve a specific surface area of approximately $500 \mathrm{~m}^{2} / \mathrm{kg}$, similar to that of the experimental cement. This grinding process was conducted using the same equipment as was used to comminute the sand. The material was immediately heated at $550^{\circ} \mathrm{C}$ (see first stage data) for $1 \mathrm{~h}$ inside a Flyevier muffle

\section{Table 4}

Cement paste composition: AC, RC, and RCQ pastes

\begin{tabular}{ccccc}
\hline Paste & W (\%) & R (\%) & O (\%) & $\begin{array}{c}\text { Ground } \\
\text { sand (\%) }\end{array}$ \\
\hline AC & 33 & 67 & 0 & 0 \\
RC & 33 & 0 & 67 & 0 \\
RCQ & 33 & 0 & 57 & 10 \\
\hline
\end{tabular}

furnace (model FE50RPM) equipped with a temperature controller to eliminate water content (free and combined) from the pastes and recover anhydrous cement phases. The duration was determined as a function of the furnace thermal power, cement paste mass, and specific heat to implement an efficient material dehydration process. The binder (O), obtained following thermomechanical treatment, was used to produce new cement pastes by replacing $15 \%$ of the thermally treated material with sand powder (RCQ pastes) and also without replacement (RC pastes). Table 4 presents the percentages of water $(\mathrm{W})$, anhydrous Portland cement $(\mathrm{R})$, recovered binder $(\mathrm{O})$, and ground sand used in each sample.

The phases present in the AC, RC, and RCQ pastes were identified using simultaneous thermogravimetric (TG) and mass spectrometry (TGMS) analyses from a PERKIN-ELMER STA-6000 simultaneous thermal analyzer coupled with a HIDEN HPR 20 quadrupole mass spectrometer. These tests were conducted at a heating rate of $10^{\circ} \mathrm{C} / \mathrm{min}$ under helium flow $(20 \mathrm{~mL} / \mathrm{min})$. X-ray diffraction was also tested using the same equipment and under the same conditions as those applied in stage 1 . The cement paste microstructures were analyzed via scanning electron microscopy with phase identification (SEM-FEG) in a Quanta FEG 3D FEI device with $0.8 \mathrm{~nm}$ resolution, 3-99 $\mathrm{mm}$ focal length, and a $24-800,000$ fold increase in high vacuum.

\section{Results and discussions}

\subsection{Evaluation of recovery temperature of anhydrous phases}

\subsubsection{Thermal analysis}

Figure 1 shows the thermal analysis of the AC paste following comminution, presenting the differential thermal analysis (DTA), TGA, and TGA-derivative curves (DrTGA). These curves are similar to the thermal analysis curves described in literature investigating the hydration of Portland cement pastes (Kovler and Roussel [6]; Ramachandran [19]; Kakali et al. [20]; Alarcon Ruiz et al. [21]; Chen et al. [22]). Three regions of significant heat and mass variations were observed. The first mass loss, occurring between $30-200{ }^{\circ} \mathrm{C}$, resulted from the dehydration reactions of several hydrates (carboaluminates, ettringite, etc.) including, primarily, calcium silicate hydrate (C-S-H) (Taylor et al. [1]). The second largest mass loss was observed between $400-550^{\circ} \mathrm{C}$, corresponding to the dehydroxylation of Portlandite (Alarcon Ruiz et al. [21]). The third mass loss appeared at approximately $650{ }^{\circ} \mathrm{C}$, where Alonso and Fernandez [12] approximated the decomposition of calcite $\left(\mathrm{CaCO}_{3}\right)$ and generation of $\mathrm{CO}_{2}$ occurred. Furthermore, calcium carbonate experiences decarbonization above $700{ }^{\circ} \mathrm{C}$ (Alonso and Fernandez [12]; Rodrigues et al. [23]; Fuentes et al. [24]). Relevant literary information indicates that it is possible to lose the water mass responsible for cement hydration at temperatures of approximately $550^{\circ} \mathrm{C}$.

\subsubsection{X-Ray diffraction}

The cement paste diffractograms taken at ambient temperature $\left(26{ }^{\circ} \mathrm{C}\right)$ were subsequently heated at $200,500,550,700$, and $750{ }^{\circ} \mathrm{C}$, as presented in Figure 2. Calcium hydroxide $(\mathrm{P})$, calcium 


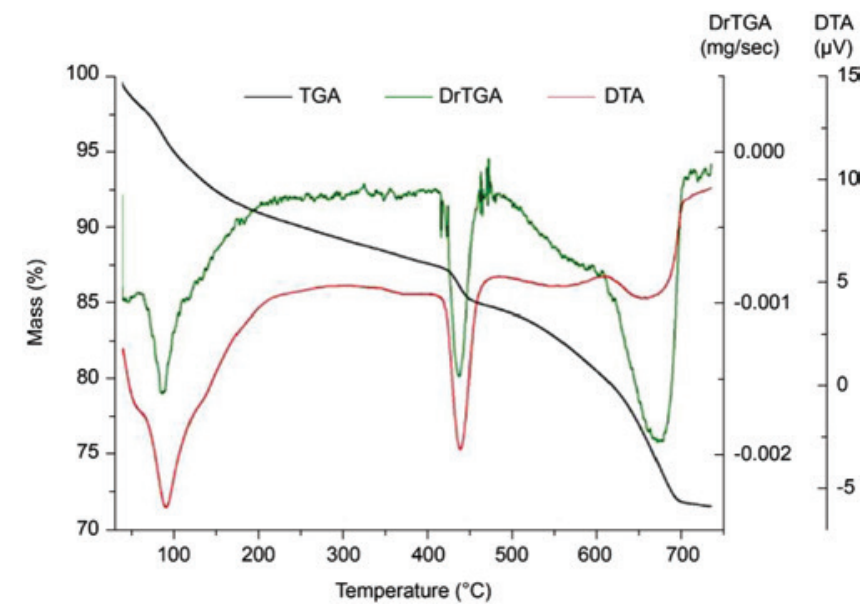

Figure 1

Thermal analysis of comminuted cement paste $(w / c 0.5)$

carbonate $(C)$, tricalcium silicate $(A)$, dicalcium silicate $(B)$, calcium aluminum hydrosulfate $(E)$, tetracalcium sulfoaluminate $(F)$, and calcium silicate hydrate $(\mathrm{H})$, constituents commonly found in Portland cement pastes (Alonso and Fernandez [12]; Shui et al. [25]), were present in unheated samples. After heating to $200^{\circ} \mathrm{C}$, calcium hydroxide $(P)$, tricalcium silicate $(A)$, calcium silicate hydrate $(\mathrm{H})$, and calcium carbonate $(\mathrm{C})$, were identified. At $500{ }^{\circ} \mathrm{C}$ the identified phases were calcium hydroxide $(P)$, tricalcium silicate $(A)$, and calcium carbonate $(C)$. Calcium hydroxide $(P)$, tricalcium silicate $(A)$, dicalcium silicate $(B)$, calcium carbonate $(C)$, and tetracalcium sulfoaluminate $(F)$ were observed at $550^{\circ} \mathrm{C}$. Crystals of tricalcium silicate $(A)$, calcium carbonate $(C)$, and calcium oxide

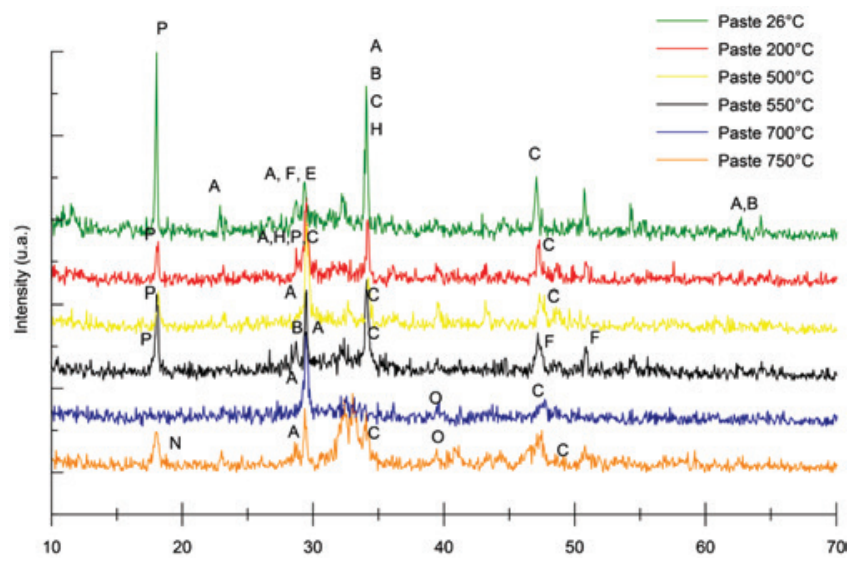

Figure 2

Diffractograms of cement pastes at ambient temperature $\left(26^{\circ} \mathrm{C}\right)$ and thermal treatments: $200,500,550,700^{\circ} \mathrm{C}$, and $750^{\circ} \mathrm{C}$. Labeled peaks: tricalcium silicate $(A)$, bicalcium silicate $(B)$, calcium carbonate (C), calcium aluminum hydrosulfate (E), tetracalcium sulfoaluminate (F), calcium silicate hydrate $(H)$, calcium hydroxide $(P)$, new silicate $(\mathrm{N})$, calcium oxide $(\mathrm{O})$
(O) were identified in paste heated at $700{ }^{\circ} \mathrm{C}$. Existing literature indicates calcium silicate hydrate, calcium oxide, and dehydrated calcium sulfoaluminate coexist at $700{ }^{\circ} \mathrm{C}$ (Schöler et al. [7]; Splittgerber and Mueller [10]; Janotka and Nürnbergerov [26]). It was noted that calcium silicate decomposed at $750^{\circ} \mathrm{C}$ into new phases, reducing the mechanical strength of the material $(\mathrm{N})$ (Splittgerber and Mueller [10]; Vieira et al. [27]; Trezza and Lavat [28]).

All cement pastes demonstrated peaks illustrating the presence of calcite, indicative of carbonation. Hydrated calcium silicate was observed in two samples: unheated, and thermally treated at $200^{\circ} \mathrm{C}$. Based on these results, thermal analysis data, and existing literature, it was determined that cement pastes treated at temperatures $>700$ ${ }^{\circ} \mathrm{C}$ may contain calcium silicate hydrates decomposed into new phases (Splittgerber and Mueller [10]; Vieira et al. [27]; Trezza and Lavat [28]). Because of this, the $700{ }^{\circ} \mathrm{C}$ temperature point was taken as a reference for anhydrous cement recovery. However, pastes produced using cement obtained by thermal treatments at this temperature exhibited insufficient cohesion for molding (Splittgerber and Mueller [10]; Trezza and Lavat [28]). Conversely, pastes produced using cement that underwent $550{ }^{\circ} \mathrm{C}$ thermal treatment exhibited satisfactory cohesion levels. A working temperature of $550{ }^{\circ} \mathrm{C}$ was consequently selected for binder recovery. Moreover, the suitability of this temperature was verified by comparing the diffractograms of cement pastes treated at $550{ }^{\circ} \mathrm{C}$ (recovered binder) to those of Portland cement (Figure 3). Both diffractograms contained the same main peak phases: calcium hydroxide $(P)$, tricalcium silicate $(A)$, dicalcium silicate $(B)$, calcium carbonate $(C)$, and calcium ferroaluminate $(F)$.

\subsection{Investigation of cement pastes produced using recovered cement with and without sand powder}

\subsubsection{Thermogravimetric analysis}

Below, the thermogravimetric analysis results of three pastes are

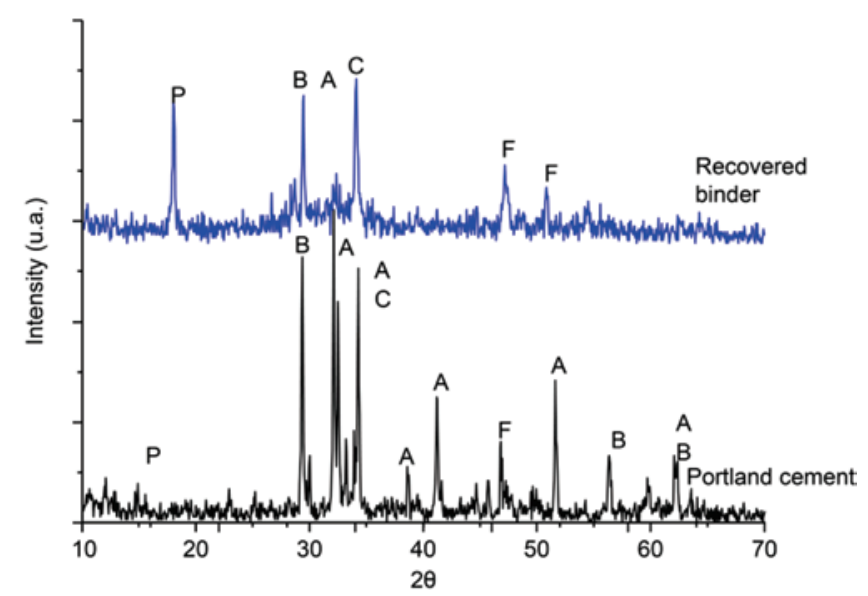

Figure 3

Diffractograms of Portland cement and recovered binder (paste thermally treated at $550^{\circ} \mathrm{C}$ ). Peaks: calcium hydroxide $(P)$, tricalcium silicate $(A)$, dicalcium silicate (B), calcium carbonate (C), calcium ferroaluminate $(F)$ 


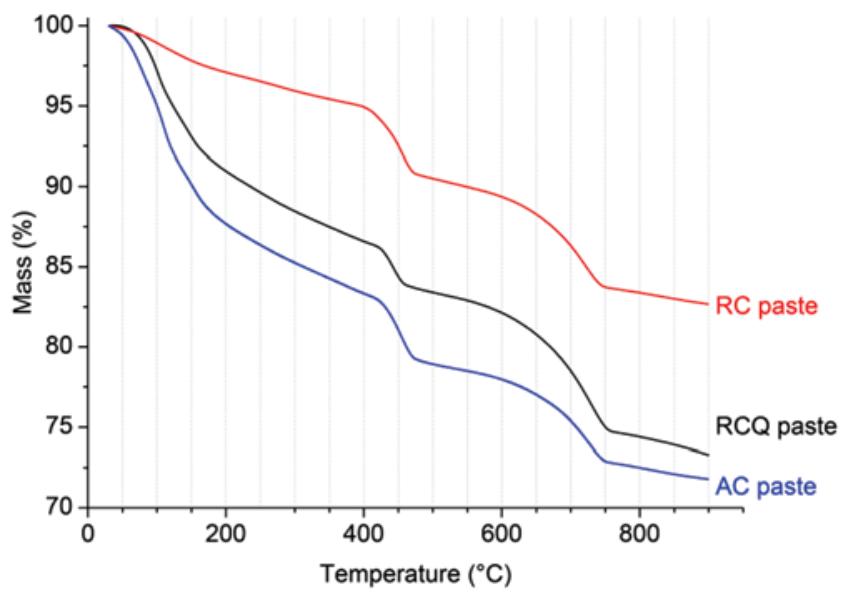

\section{Figure 4}

Thermogravimetric curves of pastes produced with anhydrous Portland cement $(A C)$, recycled cement (RC), and cement with $15 \%$ sand powder replacement (RCQ)

presented: a paste produced from Portland cement, one from recovered cement without partial replacement, and one with a partial replacement ( $15 \%$ quartz sand powder). The obtained curves, shown in Figure 4, are similar to those described in relevant literature where thermal analysis was used to investigate the hydration of Portland cement and Portland cement paste without high addition levels (Fordham and Smalley [5]; Farage et al. [9]; Alonso and Fernandez [12]; Vieira et al. [27]; Zhutovsky and Kovle [29]; Hoppe Filho et al. [30]). Observations indicate high mass losses at three critical temperatures, which synthesized the dehydration process and resembled the results obtained in step 3.1.1. The first mass loss occurred between $100-200{ }^{\circ} \mathrm{C}$ as a result of the dehydration reactions of various hydrates (Farage et al. [9]). The second significant mass decrease was observed between $400-550^{\circ} \mathrm{C}$, corresponding to the dehydration of Portlandite (Fordham and Smalley [5]; Rodrigues et al. [23]; Zhutovsky and Kovle [29]; Hoppe Filho et al. [30]). The third mass loss occurred at approximately $750^{\circ} \mathrm{C}$, corresponding to the decarbonization of calcium carbonate produced by the decomposition process of calcium silicate hydrate (C$\mathrm{S}-\mathrm{H})$ and leading to the production of calcium oxide $(\mathrm{CaO})$, which in turn reacted with $\mathrm{CO}_{2}$ in the atmosphere of the equipment to produce calcite (Alonso and Fernandez [12]; Chen et al. [22]; Shui et al. [25]; Zhutovsky and Kovle [29]).
Comparison indicated the $\mathrm{RC}$ paste experienced a greater mass loss than the RCQ paste, potentially associated with the ettringite formation resulting from interactions between calcium, sulfate, aluminate, and hydroxyl ions present in the phases identified in the cement after exposure to $550{ }^{\circ} \mathrm{C}$ temperatures (Mehta and Monteiro [2]). The lower mass loss in RCQ paste was identified in the Portlandite decomposition region, indicating a lower amount of calcium hydroxide was present and demonstrating the pozzolanic behavior of the sand powder (Benezet and Benhassaine [16]).

\subsubsection{Mass spectrometry}

Figure 5 shows the data obtained during the TGA of the volatile products released by the $A C, R C$, and $R C Q$ pastes, respectively. This data indicates two types of gases were produced when the pastes were subjected to heat: one containing hydrogen and oxygen at a temperature of approximately $450{ }^{\circ} \mathrm{C}$ (blue curve), and another containing carbon and hydrogen in the temperature range of $580-750{ }^{\circ} \mathrm{C}$ (green curve). Considering the present phases, it was deduced one of these gases was water in the gaseous state, resulting from dehydration, whereas the other was $\mathrm{CO}_{2}$ generated by the decomposition of calcium carbonate (Fordham and Smalley [5]; Ramachandran [19]; Rodrigues et al. [23]). These gases were produced by all samples at temperatures of approximately 450 and $720{ }^{\circ} \mathrm{C}$. Peak observations verified the amount of the produced $\mathrm{CO}_{2}$ was the same in the three samples, $\mathrm{AC}$, $\mathrm{RC}$ and $\mathrm{RCQ}$. However, this amount was significantly reduced in the samples of thermally treated cement and cement partially replaced by sand powder. This indicates a lower amount of dehydroxylation occurred in the Portlandite reaction, and that sand powder possesses lower pozzolanicity.

\subsubsection{X-ray diffraction}

The AC, RC, and RCQ paste diffractograms are shown in Figure 6. The phases present in the AC paste are the same as those identified in the RC paste (made from thermomechanically treated cement). The primary identified crystalline constituents were calcium carbonate $(C)$, calcium hydroxide $(P)$, hydrated calcium silicate $(H)$, dicalcium silicate $(B)$, and tricalcium silicate $(A)$. An additional peak related to the presence of silicon oxide $(Q)$ in crystalline form was identified in the RCQ paste (produced using a binder obtained via thermomechanical treatment and partial sand powder replacement) (Bacarji et al. [31]).
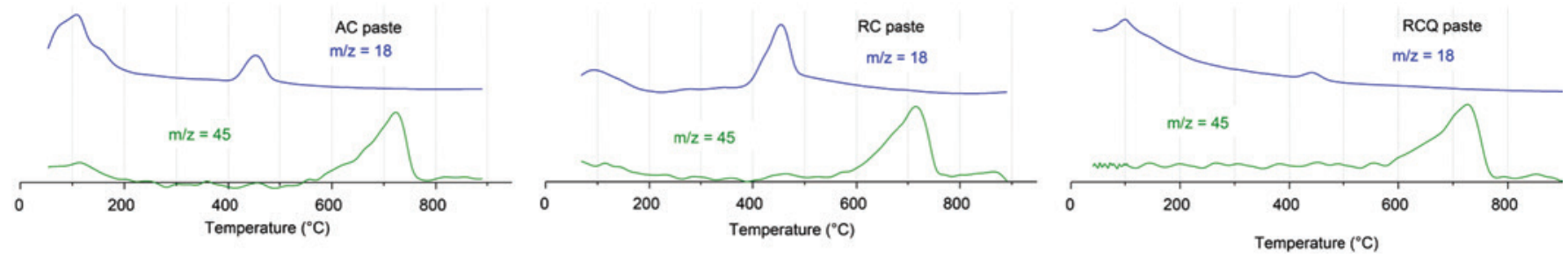

Figure 5

Volatile products released by pastes produced with anhydrous Portland cement (AC); recycled cement (RC), and 15\% replacement by sand powder (RCQ) 


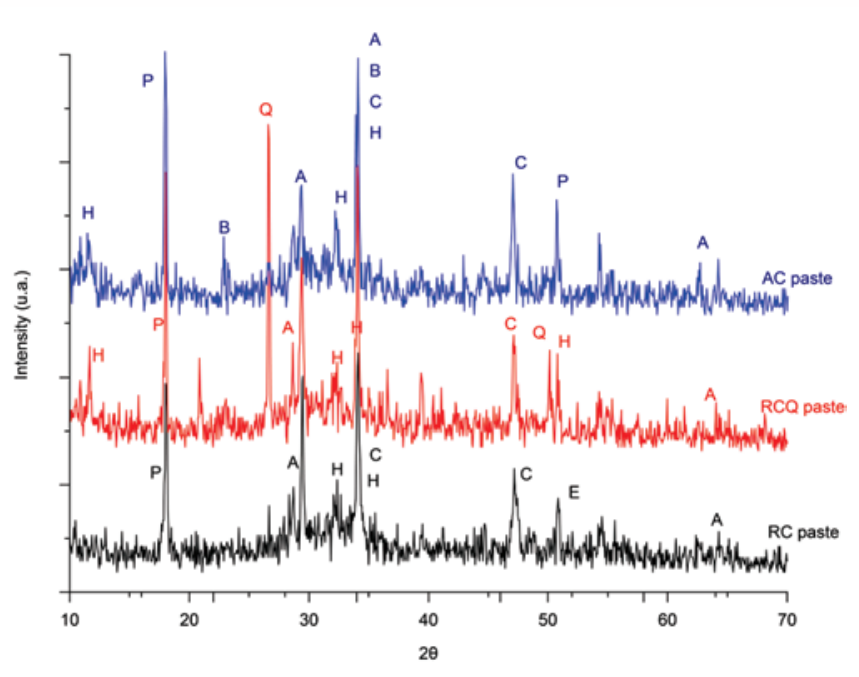

Figure 6

Diffractograms of pastes produced with anhydrous Portland cement (AC), recycled cement (RC), and $15 \%$ replacement of cement recycled by sand powder (RCQ)

\subsubsection{Microstructural analysis}

Figure 7 shows the typical AC, RC and RCQ paste microstructures. During microstructural analysis with phase identification (MEV-FEG), calcium hydroxide and hydrated calcium silicate were observed in all pastes. The presence of ettringite predominated in the RC paste image, whereas ettringite was not abundant in the AC paste image, nor present in the RCQ paste. This phenomenon may be associated with the reduced formation of ettringite caused by the interactions between calcium, sulfate, aluminate, and hydroxyl ions with water (Mehta and Monteiro [2]), and could be explained by the reaction between the sand powder and constituents of the recovered cement when subjected to hydration. This hypothesis reinforces the theory of the supplementary behavior of sand power in cement, as well as the reactivity increase caused by its comminution (Rêgo et al. [32]).

\section{Conclusions}

- Pastes made with thermomechanically treated cement $\left(550^{\circ} \mathrm{C}\right.$ and comminution) without replacement by sand powder presented primarily ettringite microstructures.

- Pastes made with heat-treated recycled cement and cement partially replaced by sand powder exhibit significantly lower amounts of gas release as compared to pastes made with CPV-ARI Portland cement or heat-treated recycled cement without sand powder substitutions, indicating the dehydroxylation reaction occurs to a lesser extent in Portlandite and the pozzolanicity of sand powder was relatively lower.

- Pastes made with cement recovered by thermomechanical treatment $\left(550{ }^{\circ} \mathrm{C}\right.$ and comminution) and partial (15\%) sand powder (specific surface area of $37 \mathrm{~m}^{2} / \mathrm{g}$ ) replacements, demonstrated similar phases to those found in CPV-ARI Portland cement, indicating it is possible to recover cements that have been subjected to this temperature.

- The simultaneous use of cement from thermally treated pastes and sand powder from quartz sand grinding demonstrated the technical viability of recovering cements and sands present in mortar and concrete residues via thermomechanical treatment.

- This study represents the first step in evaluating the reuse of cement and sand obtained from construction wastes as alternative binders; however, further complimentary research is needed.

\section{Acknowledgments}

The authors would like to thank the Foundation for Research Support of the State of Minas Gerais (FAPEMIG), the National Council for Scientific and Technological Development (CNPq), and the Coordination for the Improvement of Personnel in Higher Education (CAPES) for their financial support.

\section{References}

[1] TAYLOR, R.; RICHARDSON, I. G.; BRYDSON, R. M. D. Nature of C-S-H in 20 year old neat ordinary Portland cement and $10 \%$ Portland cement-90\% ground granulated blast
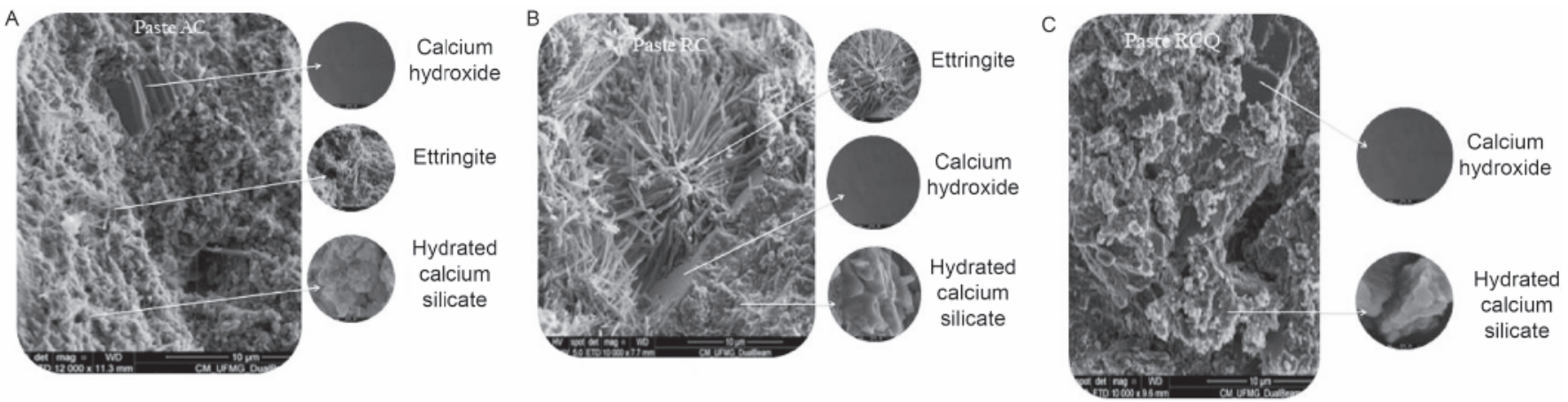

\section{Figure 7}

Characterization of paste microstructures: (A) Paste produced with anhydrous Portland cement (AC), (B) paste produced with recycled cement (RC), (C) paste produced with recycled cement and $15 \%$ replacement of the recycled cement by sand powder (RCQ) 
furnace slag pastes. Advances in Applied Ceramics, v.106, 2007; p.294-301.

[2] MEHTA, K.; MONTEIRO, P. J. M. Concrete: Microstructure, Properties, and Material, São Paulo: Ibracon, 3ed, 2008, 608 p.

[3] SHUI, Z.; XUAN, D.; WAN, H.; CAO, B. Rehydration reactivity of recycled mortar from concrete waste experienced to thermal treatment. Construction and Building Materials, v.22, n.8, 2008; p.1723-1729.

[4] LEMONIS, N.; TSAKIRIDS, P. E.; KATSIOTIS, N. S.; ANTIOHOS, S.; PAPAGEORGIOU, D.; KATSIOTIS, M. S.; BEAZIKATSIOTI, M. Hydration study of ternary blended cements containing ferronickel slag and natural pozzolan. Construction and Building Materials, v.81, 2015; p.130-139.

[5] FORDHAM, C. J.; SMALLEY, I. J. A simple thermogravimetric study of hydrated cement. Cement and Concrete Research, v.15, n.1, 1985; p.141-144.

[6] KOVLER, K.; ROUSSEL, N. Properties of fresh and hardened concrete. Cement and Concrete Research, v.41, n.7, 2011; p.775-792.

[7] SCHÖLER, A.; LOTHENBACH, B.; WINNEFELD, F.; ZAJAC, M. Hydration of quaternary Portland cement blends containing blast-furnace slag, siliceous fly ash and limestone powder. Cement and Concrete Composites, v.55, 2015; p.374-382.

[8] KAREN, L.; SCRIVENER, A.; JUILLAND, P.; MONTEIRO, P. J. M. Advances in understanding hydration of Portland cement. Cement and Concrete Research, v.78, 2015; p.38-56.

[9] FARAGE, M. C. R.; SERCOMBE, J.; GALLÉ C. Rehydration and microstructure of cement paste after heating at temperatures up to $300{ }^{\circ} \mathrm{C}$. Cement and Concrete Research, v.33, n.7, 2003; p.1047-1056.

[10] SPLITTGERBER, F.; MUELLER A. Inversion of the cement hydration as a new method for identification and/or recycling? In: International congress on the chemistry of cement, Durban, South Africa, 2003, p.1282-1290.

[11] BURGH, J. M.; FOSTER, S. J. Influence of temperature on water vapour sorption isotherms and kinetics of hardened cement paste and concrete. Cement and Concrete Research, v.92, 2017; p.37-55.

[12] ALONSO, C.; FERNANDEZ, L. Dehydration and rehydration processes of Cement paste exposed to high temperature environments. Journal of Materials Science, v.39, n.9, 2004; p.3015-3024.

[13] WANG, G.; ZHANG, C.; ZHANG, B.; LI, Q.; SHUI, Z. Study on the high-temperature behavior and rehydration characteristics of hardened cement paste. Fire and Materials, v.39, n.8, 2015; p.741-750.

[14] ZANNI, H.; CHEYREZY, M.; MARET, V.; PHILIPP, S.; NIETO, P. Investigation of hydration and pozzolanic reaction in reactive powder concrete. Cement and Concrete Research, v.26, n.1, 1996; p.93-100.

[15] KLIMESCH, D. S.; RAY, A. The use of DTA/TGA to study the effects of ground quartz with different surface areas in autoclaved cement: quartz pastes. Use of the semi-isothermal thermogravimetric technique. Thermochimica Acta, v.306, n.1-2, 1997; p.159-165.

[16] BENEZET, J. C.; BENHASSAINE, A. The influence of particle size on the pozzolanic reactivity of quartz powder. Powder Technology, v.103, n.1, 1999; p.26-29.

[17] DESCHNER, F.; WINNEFELD, F.; LOTHENBACH, B.; SEUFERT, S.; SCHWESIG, P.; DITTRICH, S.; GOETZNEUNHOEFFER, F.; NEUBAUER, J. Hydration of Portland cement with high replacement by siliceous fly ash. Cement and Concrete Research, v.42, n.10, 2012; p.1389-1400.

[18] SNIC - Sindicato Nacional da indústria do cimento. Press Kit - 2013. Available from http://www.snic.org.br/, 2013.

[19] RAMACHANDRAN, V. S. Estimation of tricalcium silicate through polymorphic transition. Journal Thermal Analysis, v.3, n.2, 1971; p.181-190.

[20] KAKALI, G.; PERRAKI, T.; TSIVILIS, S. E.; Badogiannis, E. Thermal treatment of kaolin: the Effect of mineralogy on the pozzolanic activity. Applied Clay Science, v.20, n.1-2, 2001; p.73-80.

[21] ALARCON-RUIZ, L.; PLATRETB, G.; MASSIEUB, E.; EHRLACHER, A. The use of thermal analysis in assessing the effect of temperature on a cement paste. Cement and Concrete Research, v.35, n.3, 2005; p.609-613.

[22] CHEN, X.; ZHOU, J.; YAN, Y. Hydration of ultrafine and ordinary Portland cement at early Ages. KSCE Journal of Civil Engineering, v.18, n.6, 2014; p.1720-1725.

[23] RODRIGUES, R., MONZÓ, M. S.; BORRACHERO, J.; PAYA, M. V.; BERALDO, J.; SAVASTANO JÚNIOR, A. L. Characterization and pozzolanic valuation of sugar cane bagasse ashes. In: $12^{\text {th }}$ International Conference on NonConventional Materials and Technologies for Sustainable Infrastructure Systems: Ecological Materials and Technologies for Sustainable Building, Cairo, Egypt, 2010, Proceedings of the IC-Nocmat 2010, HBRC/Abmtenc, Cairo, 2010, p.1-9.

[24] FUENTES, M.; ZÚÑIIGA, A.; DÍAZ, M.; ROCHA, E.; DÍAZ, S. Molienda mecánica por alta energía de minerales mexicanos para producir concreto de alto desempeño (CAD). Revista Ingeniería de Construcción, v.29, n.3, 2014; p.256-269.

[25] SHUI, Z.; XUAN, D.; CHEN, W.; YU, R.; ZHANG, R. Cementitious characteristics of hydrated cement paste subjected to various dehydration temperatures. Construction and Building Materials, v.23, n.1, 2009; p.531-537.

[26] JANOTKA, I.; NÜRNBERGEROVÁ, T. Effect of temperature on structural quality of the cement paste and high-strength concrete with silica fume. Nuclear Engineering and Design, v.235, n.17-19, 2005; p.2019-2032.

[27] VIEIRA, C. M. F.; DIAS, C. A. C. M.; MOTHÉ, A. V.; SÁNCHEZ, R.; MONTEIRO, S. N. Incorporation of blast furnace sludge into red ceramic. Cerâmica, v.53, n.328, 2007; p.381-387.

[28] TREZZA, M. A.; LAVAT, A. E. Analysis of the system $3 \mathrm{CaO}$. Al2O3-CaSO4.2H2O-CaCO3-H2O by FT-IR spectroscopy. Cement and Concrete Research, v.31, n.6, 2001; p.869-872.

[29] ZHUTOVSKY, S.; KOVLE, K. Hydration kinetics of high-performance cementitious systems under different curing conditions. Materials and Structures, v.46, n.10, 2013; p.1599-1611.

[30] HOPPE FILHO, J.; SOUZA, D. J.; MEDEIROS, M. H. F.; PEREIRA, E.; PORTELLA, K. F. Ataque de matrizes cimentícias por sulfato de sódio:adições minerais como agentes mitigadores. Cerâmica, v.61, n.358, 2015; p.168-177. 
[31] BACARJ, E.; TOLEDO FIHO, R. D.; KOENDERS, E. A. B.; FIGUEIREDO, E. P.; LOPES, J. L. M. P. Sustainability perspective of marble and granite residues as concrete fillers. Construction and Building materials, v.45, 2013; p.1-10.

[32] RÊGO, J. H. S.; NEPOMUCENO, A. A.; FIGUEIREDO, E. P.; HASPARYK, N. P.; BORGES, L. D. Effect of particle size of residual Rice-Husk ash in consumption of $\mathrm{Ca}(\mathrm{OH})_{2}$. Journal of Materials in civil Engineering, v.27, no.6, 2015; 04014178. 